\title{
Contextual Effect of Village on the Risk of Pneumonia in Children Under Five in Magetan, East Java
}

\author{
Yola Alqorien Mustikarani'), Setyo Sri Rahardjo²), Isna Qadridjati²), \\ Hanung Prasetya3) \\ 1)Masters Program in Public Health, Universitas Sebelas Maret \\ 2)Faculty of Medicine, Universitas Sebelas Maret \\ 3)School of Health Polytecnics, Ministry of Health Surakarta
}

\begin{abstract}
Background: Pneumonia is a major cause of illness and death in children under five worldwide. Studies into the contextual effect of village are lacking in Indonesia. This study aimed to determine contextual effect of village on the risk of pneumonia in children under five in Magetan, East Java.

Subjects and Method: This was a case control study conducted in Magetan, East Java, from October 2018 to December 2018. A sample of 225 children under five from 25 villages was selected by fixed disease sampling. The dependent variable was pneumonia. The independent variables were nutritional status, vitamin A intake, maternal stress, maternal education, family income, family smoking, cooking fuel, house physical environment, and the presence of children in the kitchen when cooking. The data were collected by questionnaire and analyzed by a multilevel logistic regression.

Results: Maternal stress $(b=1.91 ; 95 \% \mathrm{CI}=0.75$ to $3.06 ; \mathrm{p}=0.001)$, family smoking habits $(\mathrm{b}$ $=1.39 ; 95 \% \mathrm{CI}=0.46$ to $2.32 ; \mathrm{p}=0.003)$, cooking fuel $(\mathrm{b}=1.51 ; 95 \% \mathrm{CI}=0.46$ to $2.55 ; \mathrm{p}=$ $0.005)$, and the presence of children in the kitchen when cooking ( $\mathrm{b}=1.37 ; 95 \% \mathrm{CI}=0.38$ to 2.35; $\mathrm{p}=0.007$ ) increased the risk of pneumonia in children under five. The risk of pneumonia was reduced by good nutritional status $(b=-1.74 ; 95 \% \mathrm{CI}=-2.70$ to $-0.78 ; \mathrm{p}<0.001)$, complete vitamin A status $(\mathrm{b}=-1.14 ; 95 \% \mathrm{CI}=-2.04$ to $-0.24 ; \mathrm{p}=0.013)$, high maternal education $(\mathrm{b}=-$ $1.41 ; 95 \% \mathrm{CI}=-2.45$ to $-0.37 ; \mathrm{p}=0.008)$, high family income $(\mathrm{b}=-0.91 ; 95 \% \mathrm{CI}=-1.80$ to -0.02 ; $\mathrm{p}=0.045)$, and healthy home physical environment $(\mathrm{b}=-1.86 ; 95 \% \mathrm{CI}=-3.20$ to $-0.52 ; \mathrm{p}=$ 0.007). Village had a strong contextual effect on pneumonia among children under five with $\mathrm{ICC}=21.32 \%$.

Conclusions: Maternal stress, family smoking habits, cooking fuel, and the presence of children in the kitchen when cooking increase the risk of pneumonia in children under five. It is reduced by good nutritional status, complete vitamin A status, high maternal education, high family income, and healthy home physical environment. Village has a strong contextual effect on pneumonia among children under five
\end{abstract}

Keywords: pneumonia, children under five, biopsychosocial, environmental, determinants, multilevel analysis

\section{Correspondence:}

Yola Alqorien Mustikarani. Masters Program in Public Health, Universitas Sebelas Maret. Jl. Ir. Sutami 36A, Surakarta, Central Java 57126, Indonesia. Email: yolla.mstika@gmail.com. Mobile: +6285856122288

\section{BACKGROUND}

Pneumonia is a major cause of morbidity and mortality in infants and toddlers in the world. It is estimated that in 2016 around 5 million children under the age of 5 years died from pneumonia. This figure is higher 
Journal of Epideiology and Public Health (2019), 4(2): 117-126

https://doi.org/10.26911/jepublichealth.2019.04.02.07

in low and middle income countries. Data from the World Health Organization (WHO) shows that infant and under-five mortality in the world reached 43 deaths per 1000 live births and causes of death in infants and toddlers, namely pneumonia by $14 \%$, diarrhea by $14 \%$, other infections by $9 \%$, malaria of $8 \%$, and noncomunicable disease of 4\%. From 2000-2015 data from UNICEF showed that the mortality of children under five from pneumonia was 51\%. (UNICEF, 2015; Zar et al., 2016; Nguyen et al., 2017; Nair et al., 2018; WHO, 2016).

Pneumonia is not only the highest disease in the world but also in Indonesia. The incidence of pneumonia in Indonesia in 2017 was 447,431 or $46.34 \%$ of infants and toddlers. Whereas in East Java the prevalence of pneumonia in 2017 was 65,139 events or $41.93 \%$ of children under five had pneumonia. The number of pneumonia cases in infants found and handled in Magetan Regency in 2017 was 1,101 cases or $60.1 \%$, while the estimated pneumonia cases in infants were 1,833 cases (Ministry of Health., 2018; Magetan Health Office, 2017).

Many factors influence the incidence of pneumonia, both from individual children, parents, environmental, and socioeconomic behavior. Factors from individual children that can cause pneumonia are LBW, exclusive non-breastfeeding, incomeplete immunization, vitamin A deficiency, malnutrition, and preterm birth (Anwar et al, 2014; Tekle et al, 2015; Roomaney et al., 2016; Fekadu, 2014; Cardoso et al., 2015).

The factors of parent behavior or lifestyle practiced at home also determine the health of the child, such as the extent to which exposure to cooking smoke is based on the type of fuel used for cooking, household members who smoke, and there is a separate kitchen. Psychologically, maternal stress indirectly affects pneumonia, stress on mothers affects breastfeeding and the pattern of care for children under five which influences the nutritional status of children (Han, 2015; Adesanya et al, 2016).

Environmental factors such as dwellings with dense occupants, spatial planing, exposure to cigarette smoke or indoor air pollution play a role in the risk of pneumonia. The physical environment of a house that does not meet health requirements and fuel use behavior can increase the risk of various diseases, one of which is pneumonia (Anwar et al, 2014; Ewnetu, 2016).

The economic status of a region also affects the incidence of pneumonia. Poverty in a region can describe the poverty of the population. Children who live in poverty that use biomass fuel when cooking have a high risk of pneumonia. In addition, low economic status shows the low ability of the population to fulfill their basic needs, such as food, which causes malnutrition, housing ownership that does not meet requirements, and lack of access to health facilities (Adesanya et al, 2016).

This study aimed to determine contextual effect of village on the risk of pneumonia in children under five in Magetan, East Java.

\section{SUBJECTS AND METHOD}

\section{Study Design}

This was an analytic observational study with a case control design. The study was conducted in Magetan, East Java, Indonesia, from October to November 2018.

\section{Population and Samples}

The source population in this study were all toddlers in Magetan Regency. A sample of 225 children under five from 25 villages was selected by fixed disease sampling. 


\section{Study Variables}

The dependent variable was pneumonia. The independent variables were nutritional status, vitamin A status, maternal stress, maternal education, family income, family smoking habit, cooking fuel, the physical environment of the house, and the presence of children in the kitchen when cooking.

\section{Operational Definition of Variables}

The incidence of pneumonia was defined as a condition of respiratory tract infection in infants characterized by coughing and/ or difficulty in breathing accompanied by other clinical signs such as increased respiratory frequency and the pulling the lower chest wall inward. Assessment and enforcement of diagnoses by trained doctors or other health personnel. The data were obtained from medical record. The measurement scale was categorical.

Nutritional status was defined as a condition of the nutritional status of children in the last month which is calculated based on anthropometric measurements of body weight per age (WAZ). The measurement scale was continuous and transformed into dichotomous.

The status of vitamin A was defined as completeness state of vitamin A intake, which was in 100,000 IU doses for children aged 6 to 12 months and one 200,000 IU for children aged 1-5 months every six months.

Maternal stress was defined as a negative maternal emotional condition in which the mothers experience feelings of anxiety, irritability, and overreacting to situations. The data were collected by a questionnaire from Lovibond, 1995. The measurement scale was continuous and transformed into dichotomous.

Maternal education was defined as the highest formal education that has ever been taken by the mother. The data were collected by questionnaire. The measure- ment scale was categorical and transformed into dichotomous.

Family income was defined as the amount of income each month obtained by the family in the form of honorarium, rent, including subsidies or benefits expressed in rupiah. The minimum wage of Magetan Regency amounted to Rp 1,509,816. The measurement scale was continuous and transformed into dichotomous.

Family smoking was defined as the presence or absence of smoking family members who smoke near children. The measurement scale was dichotomous.

Cooking fuel was defined as fuel in the form of wood, charcoal, husks, straw, and other biomass fuels used for cooking. The data were collected by questionnaire. The measurement scale was categorical.

The physical environment of the house was defined as the condition of the physical environment of the house based on KEPMENKES Number 829/Menkes/ SK/ VII/ 1999 concerning Housing Health Requirements. The measurement scale was dichotomous.

The presence of children in the kitchen while cooking was defined as children who are in the kitchen when mothers cook and exposed to cooking fuel smoke. The measurement scale was categorical.

\section{Data Analysis}

Univariate analysis was conducted to examine frequency and percent of sample characteristics. Bivariate analysis was carried out to examine the relationship of pneumonia and the independent variables by chi-square. Multivariate analysis was conducted by a multilevel logistic regression.

\section{Research Ethics}

The research ethics include informed consent, anonymity, confidentiality, and ethical clearance. The research ethics was 
Journal of Epideiology and Public Health (2019), 4(2): 117-126

https://doi.org/10.26911/jepublichealth.2019.04.02.07

obtained from Research Ethics Committee, Faculty of Medicine, Universitas Sebelas Maret, Surakarta, Central Java, Indonesia, with no. 357/UN27.6/KEPK/2018.

$\frac{\text { RESULTS }}{\text { 1. Univariate analysis }}$

Table 1 showed the results of univariate analysis. Table 1 showed that most of the children were in the good nutritional status
(61.3\%). As many as 122 children (54.2\%) had complete vitamin A status. As many as 120 mothers $(53.3 \%)$ had low stress, 122 mothers (54.2\%) had low education, and 128 (56.9\%) had high family income. As many as 143 parents (63.6\%) did not smoke. As many as 119 families (52.9\%) cooked using biomass fuel. As many as 156 families (69.3\%) living in poor physical environment.

Table1. Univariate analysis on the determinants of pneumonia

\begin{tabular}{|c|c|c|}
\hline Characteristics & Frequency & Percentage (\%) \\
\hline \multicolumn{3}{|l|}{ Pneumonia Status } \\
\hline No & 150 & 66.7 \\
\hline Yes & 75 & 33.3 \\
\hline \multicolumn{3}{|l|}{ Nutritional Status } \\
\hline Poor & 87 & 38.7 \\
\hline Good & 138 & 61.3 \\
\hline \multicolumn{3}{|l|}{ Vitamin AStatus } \\
\hline Complete & 103 & 45.8 \\
\hline Incomplete & 122 & 54.2 \\
\hline \multicolumn{3}{|l|}{ Maternal Stress } \\
\hline Low & 120 & 53.3 \\
\hline High & 105 & 46.7 \\
\hline \multicolumn{3}{|l|}{ Maternal Education } \\
\hline Low & 122 & 54.2 \\
\hline High & 103 & 45.8 \\
\hline \multicolumn{3}{|l|}{ Family Income } \\
\hline Low & 97 & 43.1 \\
\hline High & 128 & 56.9 \\
\hline \multicolumn{3}{|l|}{ Smoking habit } \\
\hline No & 143 & 63.6 \\
\hline Yes & 82 & 36.4 \\
\hline \multicolumn{3}{|l|}{ Cooking Fuel } \\
\hline Not Using Biomass & 106 & 47.1 \\
\hline Using Biomass & 119 & 52.9 \\
\hline \multicolumn{3}{|l|}{ House Physical Environment } \\
\hline Unhealthy & 156 & 69.3 \\
\hline Healthy & 69 & 30.7 \\
\hline \multicolumn{3}{|c|}{ Child Presence in the Kitchen } \\
\hline No & 132 & 58.7 \\
\hline Yes & 93 & 41.3 \\
\hline \multicolumn{3}{|l|}{ Village level } \\
\hline Swadaya & 36 & 16 \\
\hline Swakarya & 126 & 56 \\
\hline Swasembada & 63 & 28 \\
\hline
\end{tabular}

\section{Bivariate analysis}

Bivariate analysis was used to see the relationship between one independent varia- bles (nutritional status, vitamin A status, maternal stress, maternal education, family income, family smoking, cooking fuel, 
home physical environment, and the presence of children in the kitchen when cooking) with dependent variable (pneu- monia). The results of bivariate analysis can be seen in Table 2.

Table 2. Bivariate analysis on the determinants of pneumonia

\begin{tabular}{|c|c|c|c|c|c|c|c|}
\hline \multirow{3}{*}{ Group Variables } & \multicolumn{4}{|c|}{ Pneumonia Status } & \multirow{3}{*}{ OR } & \multirow{3}{*}{ 95\% CI } & \multirow{3}{*}{$\mathbf{p}$} \\
\hline & \multicolumn{2}{|c|}{$\begin{array}{c}\text { Non } \\
\text { Pneumonia }\end{array}$} & \multicolumn{2}{|c|}{ Pneumonia } & & & \\
\hline & $\mathbf{N}$ & $\%$ & $\mathbf{N}$ & $\%$ & & & \\
\hline \multicolumn{8}{|l|}{ Nutritional Status } \\
\hline Poor & 40 & 46 & 47 & 54 & 0.22 & $0.12-0.39$ & $<0.001$ \\
\hline Good & 110 & 79.7 & 28 & 20.3 & & & \\
\hline \multicolumn{8}{|l|}{ Vitamin A Status } \\
\hline Incomplete & 53 & 51.5 & 50 & 48.5 & 0.27 & $0.15-0.49$ & $<0.001$ \\
\hline Complete & 97 & 79.5 & 25 & 20.5 & & & \\
\hline \multicolumn{8}{|l|}{ Maternal Stress } \\
\hline Low & 101 & 84.2 & 19 & 15.8 & 6.07 & $3.26-11.32$ & $<0.001$ \\
\hline High & 49 & 46.7 & 56 & $53 \cdot 3$ & & & \\
\hline \multicolumn{8}{|l|}{ Maternal Education } \\
\hline Low & 67 & 54.9 & 55 & 45.1 & 0.29 & $0.16-0.54$ & $<0.001$ \\
\hline High & 83 & 80.6 & 20 & 19.4 & & & \\
\hline \multicolumn{8}{|l|}{ Family Income } \\
\hline Low $(<\operatorname{Rp} 1,509,816)$ & 53 & 54.6 & 44 & 45.4 & 0.38 & $0.22-0.68$ & 0.001 \\
\hline High $(\geq R$ R1,509,816) & 97 & 75.8 & 31 & 24.2 & & & \\
\hline \multicolumn{8}{|l|}{ Smoking } \\
\hline No & 110 & 76.9 & 33 & 23.1 & 3.50 & $1.96-6.26$ & $<0.001$ \\
\hline Yes & 40 & 48.8 & 42 & 51.2 & & & \\
\hline \multicolumn{8}{|l|}{ Biomass Cooking Fuel } \\
\hline Not Using & 85 & 80.2 & 21 & 19.8 & 3.36 & $1.89-6.12$ & $<0.001$ \\
\hline Using & 65 & 66.7 & 54 & 45.4 & & & \\
\hline \multicolumn{8}{|l|}{ House Physical } \\
\hline \multicolumn{8}{|l|}{ Environment } \\
\hline Poor & 96 & 61.5 & 60 & 38.5 & 0.44 & $0.23-0.86$ & 0.015 \\
\hline Good & 54 & 78.3 & 15 & 21.7 & & & \\
\hline \multicolumn{8}{|l|}{$\begin{array}{l}\text { Child Presence in the } \\
\text { Kitchen while Cooking }\end{array}$} \\
\hline No & 105 & 79.5 & 27 & 20.5 & 4.15 & $2.31-7.46$ & $<0.001$ \\
\hline Yes & 45 & 48.4 & 48 & 51.6 & & & \\
\hline
\end{tabular}

Table 2 showed that maternal stress $(\mathrm{OR}=$ $6.07 ; 95 \% \mathrm{CI}=3.26$ to $11.32 ; \mathrm{p}<0.001)$, family smoking habit $(\mathrm{OR}=3.50$; $95 \% \mathrm{CI}=$ 1.96 to $6.26 ; \mathrm{p}<0.001)$, cooking fuel using biomass $(\mathrm{OR}=3.36$; $95 \% \mathrm{CI}=1.89$ to 6.12 ; $\mathrm{p}<0.001)$, and child presence in the kitchen while cooking $(\mathrm{OR}=4.15$; $\mathrm{CI} 95 \%=2.31$ to 7.46; $\mathrm{p}<0.001)$ increased the risk of pneumonia. Good nutritional status $(\mathrm{OR}=$ $0.22 ; 95 \% \mathrm{CI}=0.12$ to $0.39 ; \mathrm{p}<0.001)$, complete vitamin A status $(\mathrm{OR}=0.27 ; 95 \%$
$\mathrm{CI}=0.15$ to $0.49 ; \mathrm{p}<0.001)$, high maternal education $(\mathrm{OR}=0.29 ; 95 \% \mathrm{CI}=0.16$ to o.54; $\mathrm{p}<0.001)$, high family income $(\mathrm{OR}=$ $0.38 ; 95 \% \mathrm{CI}=0.22$ to $0.68 ; \mathrm{p}=0.001$ ), and good house physical environment $(\mathrm{OR}=$ $0.44 ; 95 \% \mathrm{CI}=0.23$ to $0.86 ; \mathrm{p}=0.015$ ) reduced the risk of pneumonia among children under five.

\section{Multilevel Analysis}

Table 3 showed the result of multilevel logistic regression. 
Journal of Epideiology and Public Health (2019), 4(2): 117-126

https://doi.org/10.26911/jepublichealth.2019.04.02.07

Table 3. The result of multilevel logistic regression

\begin{tabular}{|c|c|c|c|c|}
\hline \multirow{2}{*}{ Independent Variables } & \multirow{2}{*}{ b } & \multicolumn{2}{|c|}{$95 \%$ CI } & \multirow[b]{2}{*}{$\mathbf{p}$} \\
\hline & & Lower Limit & Upper Limit & \\
\hline \multicolumn{5}{|l|}{ Fixed Effect } \\
\hline Nutritional Status & -1.74 & -2.70 & -0.78 & $<0.001$ \\
\hline Vitamin A Status & -1.14 & -2.04 & -0.24 & 0.013 \\
\hline Maternal Stress & 1.91 & 0.75 & 3.06 & 0.001 \\
\hline Maternal Education & -1.41 & -2.45 & -0.37 & 0.008 \\
\hline Family Income & -0.91 & -1.80 & -0.02 & 0.045 \\
\hline Family’s Smoking & 1.39 & 0.46 & 2.32 & 0.003 \\
\hline Cooking Fuel & 1.51 & 0.46 & 2.55 & 0.005 \\
\hline Home Physical Environment & -1.86 & -3.20 & $-0.5^{2}$ & 0.007 \\
\hline Child Presence in the Kitchen & 1.37 & 0.38 & 2.35 & 0.007 \\
\hline \multicolumn{5}{|l|}{ Random Effect } \\
\hline Village & 0.89 & 0.11 & $7 \cdot 30$ & \\
\hline \multicolumn{5}{|l|}{ Var (constants) } \\
\hline \multicolumn{5}{|l|}{ Log likehood $=-78.81$} \\
\hline LR test vs. Logistic Regression: & $p=0.094$ & & & \\
\hline chibar2 $(01)=1.73$ & & & & \\
\hline $\mathrm{ICC}=21.32 \%$ & & & & \\
\hline
\end{tabular}

Table 3 showed that nutritional status $(\mathrm{b}=-1.74 ; 95 \% \mathrm{CI}=-2.70$ to $-0.78 ; \mathrm{p}=$ $<0.001)$, vitamin A status ( $b=-1.14 ; 95 \%$ $\mathrm{CI}=-2.04$ to $-0.24 ; \mathrm{p}=0.013)$, maternal stress $(b=1.91 ; 95 \% \mathrm{CI}=0.75$ to $3.06 ; \mathrm{p}=$ o.001), maternal education $(b=-1.41 ; 95 \%$ $\mathrm{CI}=-2.45$ to $-0.37 ; \mathrm{p}=0.008$ ), high family income $(b=-0.91 ; 95 \% \mathrm{CI}=-1.80$ to -0.02 ; $\mathrm{p}=0.045$ ), and child presence in the kitchen while cooking $(b=1.37 ; 95 \% \mathrm{CI}=$ 0.38 to $2.35 ; \mathrm{p}=0.007$ ), and good house physical environment $(\mathrm{b}=-1.86 ; 95 \% \mathrm{CI}=-$ 3.20 to $-0.52 ; \mathrm{p}=0.007$ ) reduced the risk of pneumonia.

Family smoking habit $(b=1.39 ; 95 \%$ $\mathrm{CI}=0.46$ to $2.32 ; \mathrm{p}=0.003$ ) and cooking fuel using biomass $(\mathrm{b}=1.51 ; 95 \% \mathrm{CI}=0.46$ to $2.55 ; \mathrm{p}=0.005$ ) increased the risk of pneumonia in children under five. Village had contextual effect on pneumonia among children under five with ICC $=\mathbf{2 1 . 3 2} \%$.

\section{\begin{tabular}{lll}
\hline \multicolumn{4}{c}{ DISCUSSION } \\
\hline 1. Effect of nutritional status on
\end{tabular} pneumonia}

The result of the study showed that there an association between nutritional status on pneumonia. Children wih good nutritional status had lower risk of pneumonia by 1.74 .

Malnutrition was a major contributor to the incidence of pneumonia in toddlers. This malnutrition could cause a defect in the immune response mediated by cells so that it predisposed to infection (Champatiray et al., 2017).

Children with malnutrition were more susceptible to diseases, one of them was pneumonia. Lack of nutritions could lead to weak natural body defenses of children and children became more susceptible to infectious agents including pneumonia (Fekadu, 2014; Cardoso et al., 2015).

\section{Effect of vitamin A status on pneumonia}

The result of the study showed that there was a significant effect of vitamin A status on pneumonia in children under five. Children with complete vitamin A status reduced the risk of pneumonia 1.14 times.

Vitamin A was described as an antiinfective vitamin because of its role in regulating the immune function of the human body. One of the functions of vitamin A was the maintenance of cell 
functions for the immune system. Vitamin A deficiency could be susceptible to infection and more likely to be exposed to respiratory disease(Imdad et al., 2017).

\section{The effect of maternal stress on pneumonia}

The result of the study showed that there was a significant effect of maternal stress on pneumonia in children under five. Children who had mother with high stress increases the risk of pneumonia 1.91 times.

Psychological stress on a mother can affect parenting for children. A toddler has not been able to fulfill his/her own needs, so the role of mothers in childcare was very important. Maternal stress can disrupted the role of a mother. Mothers cannot focus on taking care of their children so they cannot pay attention to the basic needs that were good for children, such as clean environments and nutritious food (Lestari et al, 2017; Han, 2015).

\section{The effect of maternal education on the incidence of pneumonia}

The result of the study showed that there was a significant effect of maternal education on pneumonia in children under five. Children with high maternal education had lower risk of pneumonia by 1.41 times.

This was in line with a study by Ayalneh et al. (2017) which stated that there was an effect of maternal education on pneumonia. The status of maternal education was related to gaps in prevention behavior and utilization of medical services. Parents with low educational level was a predispose to poor medical services and low pneumonia prevention behavior (Ayalneh et al., 2017).

In addition, maternal education would determine the quality of care, social, and environmental factors given to the child. Mothers who were highly educated would determine the welfare of infants and children which related to their health and care (Tazinya et al., 2018)

\section{The effect of family income on pneumonia}

The result of the study showed that there was a significant effect of family income on pneumonia. Children who lived with high family income reduced the risk of pneumonia by 0.91 times.

Families with low income have a higher chance in terms of their limitations and health conditions. In addition, a high level of income would also provide a greater opportunity to have more residence that fulfill the requirements to avoid environmental-based diseases such as pneumonia (Azab et al., 2014).

Socio-economic factors were important in the incidence of pneumonia associated with nutritional status. High family income affected the fulfillment of food needs so that it can guarantee an optimal nutrition. Adequate nutritional needs lead to good children's nutritional status and good body's immune (Lestari et al, 2017).

\section{The effect of family smoking habit on the incidence of pneumonia}

The result of the study showed that there was a significant effect of parental smoker on pneumonia. Children who lived with parental smoker can increase the risk of pneumonia by 1.39 times compared to children who lived with non-parental smoker.

This was in line with a study by Tazinya et al. (2018) which showed that passive smokers increased the risk of pneumonia in toddlers by 4.67 times compared to passive nonsmokers. This was because cigarettes damaged the protection mechanism of the respiratory tract so that pathogens were easier to enter the respiratory tract and caused pneumonia (Tazinya et al., 2018). 
Journal of Epideiology and Public Health (2019), 4(2): 117-126

https://doi.org/10.26911/jepublichealth.2019.04.02.07

\section{The effect of cooking fuel on pneumonia}

The result of the study showed that there was a significant effect of cooking fuel on the incidence of pneumonia in toddlers. Toddlers who havefamily who used biomass cooking fuel can increase the risk of pneumonia in toddlers by 1.51 times compared to toddlers who have family who did not use biomass cooking fuel.

The result of this study was in line with a study by Praygod et al. (2016) which explained thatthe use of biomass cooking fuel can increase the risk of pneumonia by five times. Cases of severe pneumonia can be prevented by reducing indoor air pollution because indoor air pollution can increase the risk of pneumonia by increasing the process of infection by pathogenic pneumonia (PrayGod et al., 2016).

Pneumonia could occur if the exposure of pollutants contained in cooking fuels biomass attacked the respiratory epithelial cells and disrupted the immune system (PrayGod et al., 2016).

\section{The effect of house physical envi- ronment on pneumonia}

The result of the study showed that there was a significant effect of home physical environment on the incidence of pneumonia in toddlers. Toddlers who have houses with a healthy physical environment can reduce the risk of pneumonia by 1.86 times compared to toddlers who have houses with an unhealthy physical environment.

Unhealthy physical environment of the house can affect the incidence of pneumonia. Unhealthy physical environment with indoor air pollution and dwelling density increased the risk of pneumonia. Family members of $>4$ and inadequate ventilation can increase the moisture and cause pneumonia-causing pathogens to develop well (Gothankar et al., 2018).

\section{The effect of child presence in the kitchen while cooking on pneumonia}

The result of the study showed that there was a significant effect of the presence of children in the kitchen while cooking on pneumonia. Children who were in the kitchen while cooking increased the risk of pneumonia 1.37 times compared to toddlers who were not in the kitchen while cooking.

Children who were in the kitchen while cooking breathe more household air pollution from burning solid fuels when cooking. Especially for households that use biomass cooking fuel. Biomass stoves have the potential to increase exposure to household air pollution so that it can cause pneumonia. Air pollutants associated with the use of biomass fuels and low toddler immunity could affect respiratory pathogens (Fekadu, 2014; Tekle et al, 2015; Kelly et al., 2018).

\section{The effect of village on pneu- monia}

The result of this study showed the score of ICC $=21.32 \%$, the indicator showed that the variation in the incidence of pneumonia in toddlers by $21.32 \%$ was determined by variables at the village level. The results of multilevel analysis showed that there was a contextual effect on the condition of the village area and that this effect was important to note. Epidemiological triangle theory explained that the occurrence of a disease was caused by the presence of host factors, the agent, and the environment. The environment outside the individual played an important role in increasing pneumonia in toddlers (Murti, 2016).

The reason for this difference was because there were gaps in the utilization of services utilization and family behavior which caused the toddlers to suffer from pneumonia between people in developed 
and isolated villages (Gothankar et al., 2018).

\begin{tabular}{l}
\hline REFERENCES \\
\hline Adesanya OA, Chiao C (2016). A multilevel \\
analysis of lifestyle variations in \\
symptoms of acute respiratory infec- \\
tion among young children under five \\
in Nigeria, BMC Public Health. BMC \\
Public Health, 16(1): 1-11. doi: 10.11- \\
86/s12889-016-3565-0.
\end{tabular}

Anwar A, Dharmayanti I (2014). Pneumonia pada Anak Balita di Indonesia. Jurnal Kesehatan Masyarakat Nasional, 8(8): 359-365.

Ayalneh AA, Fetene DM, Lee TJ (2017). Inequalities in health care utilization for common childhood illnesses in Ethiopia: evidence from the 2011 Ethiopian Demographic and Health Survey. International Journal for Equity in Health: 1-9. doi: 10.1186/s12939-017-0561-7.

Azab S, Sherief LM, Saleh SH, Elshafie MA, Abdelsalam SM (2014). Impact of the socioeconomic status on the severity and outcome of community-acquired pneumonia among Egyptian children: a cohort study.Infectious Diseases of Poverty, 3(1): 14. doi: 10.1186/20499957-3-14.

Budijanto D (2016). Data and information indonesia health profile 2016. http://www.depkes.go.id/resources/download/pusdatin/lain-lain/Data dan Informasi Kesehatan Profil Kesehatan Indonesia 2016 - smaller size web.pdf. Diakses 15 April 2018

Cardoso AM, Horta BL, Santos RV, Escobar AL, Welch JR, Coimbra CEA (2015). Prevalence of pneumonia and associated factors among indigenous children in Brazil: Results from the First National Survey of Indigenous People's Health and Nutrition. Inter- national Health, 7(6): 412-419. doi: 10.1093/inthealth/ihvo23.

Champatiray J, Sataphaty J, Kashyap B, Mondal D (2017). Clinico-aetiological study of severe and very severe pneumonia in two months to five years children in a tertiary health care centre in Odisha, India. Pediatrics Section, 11(9): 10-14. doi: 10.7860/JCDR/2017/26027.10595.

Dinas Kesehatan Kabupaten Magetan. (2017). Profil kesehatan, Profil Dinas Kesehatan Tahun 2017. Diakses 20 April 2018.

Dinas Kesehatan Provinsi Jatim (2017). Profil Kesehatan Provinsi Jawa Timur Tahun 2017. http://www.depkes.go.id/resources/download/profil/PROFI L_KES_PROVINSI_2017/15_Jatim_ 2016.pdf. Diakses 20 April 2018.

Ewnetu H (2016). Determinants of community acquired pneumonia among children in Kersa District, Southwest Ethiopia: Facility Based Case Control Study.Journal of Pediatrics \& Neonatal Care, 5(2): 1-8. doi: 10.15406/jpnc.2016.05.00179.

Fekadu AG (2014). Prevalence of Pneumonia among under- five Children in Este Town and the Surrounding Rural Kebeles, Northwest Ethiopia; A Community Based Cross Sectional Study. Science Journal of Public Health, 2(3): 150. doi: 10.11648/j.sjph.20140203.12.

Gothankar J, Doke P, Dhumale G, Pore P, Lalwani S, Quraishi S, Murarkar S (2018). Reported incidence and risk factors of childhood pneumonia in India: a community-based cross-sectional study.BMC Public Health. 1-11.

Han NTN, Pongjaturawit Y, Chaimongkol N (2015). Factors related to self-efficacy in caring for young children with pneumonia among Vietnamese mo- 
Journal of Epideiology and Public Health (2019), 4(2): 117-126

https://doi.org/10.26911/jepublichealth.2019.04.02.07

thers. Moving Forward to a Prosperous and Sustainable Community: $323-330$.

Imdad A, Mayowilson E, Herzer K, Bhutta ZA (2017). Vitamin A supplementation for preventing morbidity and mortality in children from six months to five years of age. Cochrane Database of Systematic Reviews, (3). doi: 10.1002/14651858.CDoo8524.pub3.

Kelly CA, Crampin AC, Mortimer K, Dube A, Malava J, Johnston D, Unterhalter E, Glynn JR (2018). From kitchen to classroom: Assessing the impact of cleaner burning biomass-fuelled cookstoves on primary school attendance in Karonga district, northern Malawi.PLoS ONE, 13(4): 1-18. doi: 10.1371/journal.pone.0193376.

Lestari N, Salimo H, Suradi (2017). Role of Biopsychosocial Factors on the Risk of Pneumonia in Children Under-Five Years Old at Dr. Moewardi Hospital Surakarta.Journal of Maternal and Child Health, 2(2): 162-175. doi: https://doi.org/10.26911/thejmch.20 17.02.02.07.

Murti B (2016). Prinsip dan Metode Riset Epidemiologi. Surakarta: Yuma Pustaka.

Nair S, Lewis LE, Godinho MA, Murthy S, Lakiang T, Venkatesh BT (2018). Factors associated with neonatal pneumonia in India: Protocol for a systematic review and planned meta-analysis. BMJ Open, 8(1). doi: 10.1136/bmjopen-2017-018790.

Nguyen TKP, Tran TH, Roberts CL, Fox GJ, Graham SM, Marais BJ (2017). Child pneumonia - focus on the Western Pacific Region. Paediatric Respiratory Reviews. Elsevier Ltd, 21: 102-110. doi: 10.1016/j.prrv.2016.07.004.

PrayGod G, Mukerebe C, Magawa R, Jere- miah K, Torok ME (2016). Indoor Air Pollution and Delayed Measles Vaccination Increase the Risk of Severe Pneumonia in Children: Results from a Case-Control Study in Mwanza, Tanzania. PLoS ONE, 11(8): 1-13.

Roomaney RA, Wyk VP, Awotiwon OF, Dhansay A, Groenewald P, Joubert JD, Nglazi MD, Nicol E, Bradshaw D (2016) Epidemiology of lower respiratory infection and pneumonia in South Africa (1997-2015): A systematic review protocol.BMJ Open, 6(9): 1-6. doi: 10.1136/bmjopen-2016-012154.

Tazinya AA, Ekane GEH, Mbuagbaw LT, Abanda M, Atashili J, Obama MT (2018). Risk factors for acute respiratory infections in children under five years attending the Bamenda Regional Hospital in Cameroon. BMC Pulmonary Medicine: 1-8. doi: 10.1186/s12890-018-0579-7.

Tekle AG, Worku A, Berhane Y (2015). Factors associated with acute respiratory infection in children under the age of 5 years: evidence from the 2011 Ethiopia Demographic and Health Survey. Pediatric Health, Medicine and Therapeutics: 9. doi: 10.2147/PHMT.S77915.

UNICEF (2015). Pneumonia The Deadliest Childhood Disease. https://data.unicef.org/wp-content/uploads/2015/12/World-Pneumonia-Day-Infographic_242.pdf. Diakses 21 April 2018.

Zar HJ, Barnett W, Stadler A, Lubbe SG, Myer L, Nicol M (2016). Aetiology of childhood pneumonia in a well vaccinated South African birth cohort: A nested case-control study of the Drakenstein Child Health Study. The Lancet Respiratory Medicine. Elsevier Ltd, 4(6): 463-472. 